\title{
Thunderstorm incidence in southeastern Brazil estimated from different data sources
}

\author{
O. Pinto Jr., K. P. Naccarato, and I. R. C. A. Pinto \\ Instituto Nacional de Pesquisas Espaciais, São José dos Campos, Brazil \\ Correspondence to: O. Pinto Jr. (osmar@dge.inpe.br)
}

Received: 13 February 2013 - Revised: 25 May 2013 - Accepted: 13 June 2013 - Published: 9 July 2013

\begin{abstract}
This paper describes a comparative analysis of the thunderstorm incidence in southeastern Brazil obtained from thunderstorm days observed at two different epochs (from 1910 to 1951 and from 1971 to 1984) and from lightning data provided by the Brazilian lightning location system RINDAT (from 1999 to 2006) and the Lightning Imaging Sensor (LIS) on board the Tropical Rainfall Measuring Mission (TRMM) satellite (from 1998 to 2010). The results are interpreted in terms of the main synoptic patterns associated with thunderstorm activity in this region, indicating that the prevailing synoptic pattern associated with thunderstorm activity is the occurrence of frontal systems and their modulation by the South Atlantic Convergence Zone (SACZ) and topography. Evidence of urban effects is also found. The results are also discussed in the context of practical applications involving their use in the Brazilian lightning protection standards, suggesting that the present version of the Brazilian standards should be revised incorporating RINDAT and LIS data. Finally, the results are important to improve our knowledge about the limitations of the different techniques used to record the thunderstorm activity and support future climatic studies.
\end{abstract}

Keywords. Meteorology and atmospheric dynamics (atmospheric electricity; climatology; lightning)

\section{Introduction}

The thunderstorm incidence in a given place can be recorded by different techniques. The first technique used to record thunderstorm activity was to record the number of days per year in which an observer heard thunder at any time of the day. This technique was called thunderstorm days - TD (WMO, 1953; Rakov and Uman, 2003). This technique has been used since the end of the 19th century for different applications (e.g., Changnon Jr. and Hsu, 1984; Pinto Jr., 2009; Bielec-Bakowska and Lupikasza, 2009; Wei et al., 2011). One of the main applications of TD is to provide information for lightning protection standards through the so-called isoceraunic maps (Rakov and Uman, 2003). Such maps have been extensively used in many national lightning protection standards. More recently, these maps have been replaced by lightning density maps obtained by lightning location systems (LLSs) or optical satellite instruments (Diendorfer et al., 2009). Another important application of TD data is the study of climatic changes in the thunderstorm activity (Pinto Jr. and Pinto, 2008).

In the second half of the 20th century, other techniques to monitor the thunderstorm activity became available - the lightning location systems. More recently optical lightning sensitive sensors on board satellites have been used to monitor thunderstorm activity on a large scale. However, all techniques have limitations. For instance, TD values are subject to limitations related to changes in the operational man-made procedure adopted to make the observations. Also changes in the environment or the local orography around the observational site may influence the maximum distance from the site that thunder is heard. More details about the other limitations are described elsewhere (Changnon Jr. and Hsu, 1984). In turn, observations by LLS and optical sensors are subject to changes in the sensor detection efficiency due to variations in ground conductivity, satellite orbit, among others.

This paper describes a comparative analysis of the lightning incidence in southeastern Brazil obtained from thunderstorm days observed at two different epochs (from 1910 to 1951 and from 1971 to 1984) and from lightning data provided by the Brazilian lightning location system RINDAT (from 1999 to 2006) and by the Lightning Imaging Sensor 


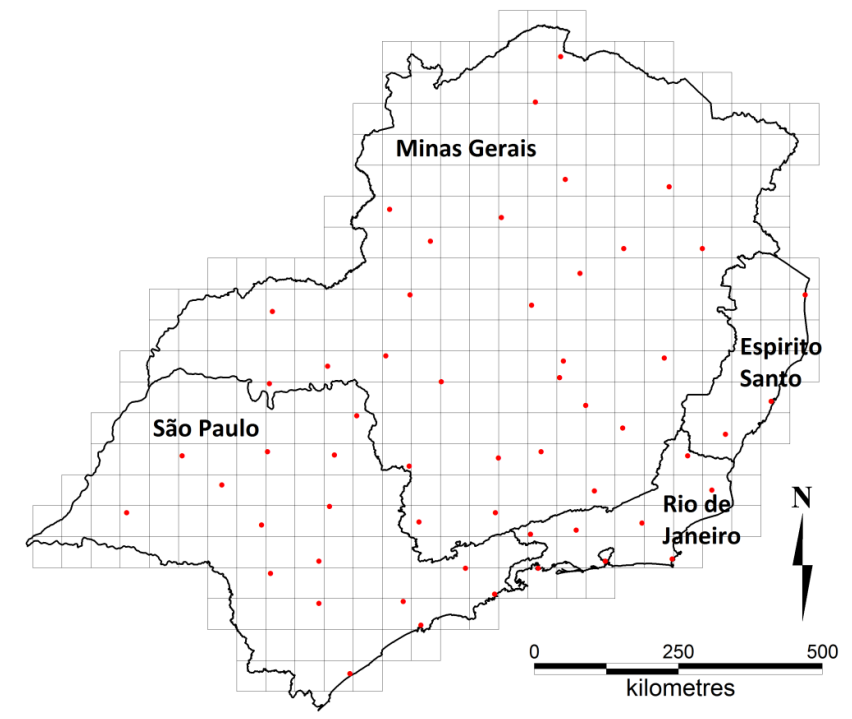

Fig. 1. Location of the 53 observation sites in southeastern Brazil used to record thunderstorm days from 1910 to 1951 . The names of the states are also indicated.

(LIS) on board the Tropical Rainfall Measuring Mission (TRMM) satellite (from 1998 to 2010). Previous comparative analyses in Brazil (Pinto and Pinto Jr. 2003) were limited to a smaller number of data sources and data samples. The analysis here is restricted to this region of Brazil due to fact that it is a unique region of the country where thunderstorm day data for two different epochs and RINDAT data are available.

In the southeastern region of Brazil, the main synoptic patterns associated with thunderstorm activity are believed to be the occurrence of frontal systems (Cavalcanti and Kousky, 2003) and local convection related to topography (Campos et al., 2011), although no detailed study exists. Frontal systems are frequent throughout the whole year, come from Argentina and sometimes are preceded by deep convection, called prefrontal (Andrade, 2007). Their frequency of occurrence is modulated by many mechanisms, among them the so-called South Atlantic Convergence Zone (SACZ), a prominent band of cloudiness extending from the Amazon region to the subtropical Atlantic Ocean, passing over the southeastern region (Carvalho et al., 2002), and by blocking anticyclones (Wiedenmann et al., 2002), which in turn are influenced by large-scale phenomena such as El Niño-Southern Oscillation (ENSO; Barros et al., 2002; Wiedenmann et al., 2002). The SACZ is developed when the convection from a cold front is coupled with the Amazonian convection, forming a zone of heavy precipitation oriented northwest-southeast all along Brazil that lasts for several days to weeks.

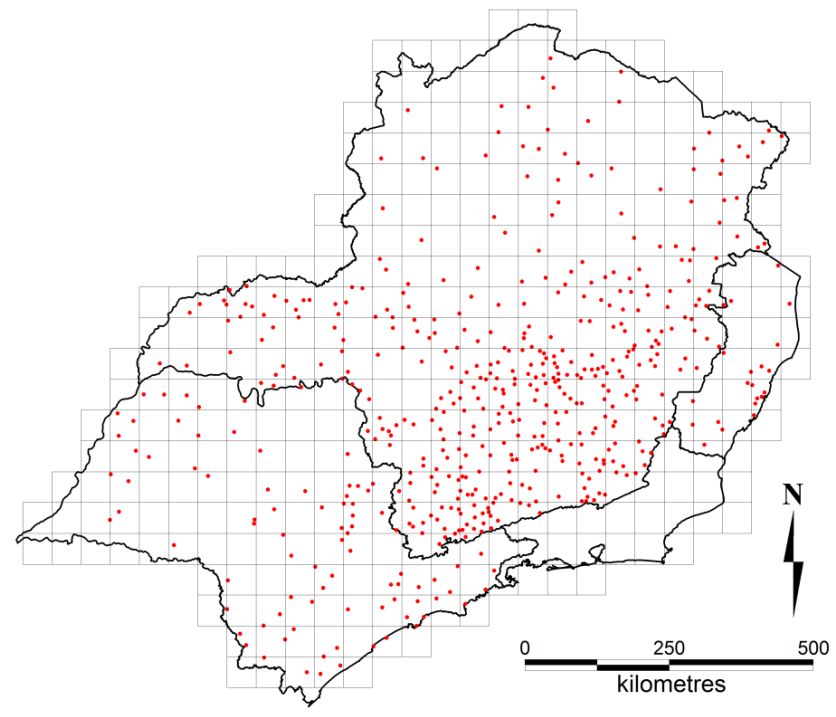

Fig. 2. Location of the 500 observation sites in southeastern Brazil used to record thunderstorm days from 1971 to 1984 .

\section{Datasets and methodology}

Three different data sources related to the thunderstorm activity were used in this study. The first set of data comes from man-made TD observations in two different epochs. One corresponds to observations made in the first half of the 20th century between 1910 and 1951 from a small (53) number of observation sites, and the period of observations at different sites varies from 5 to 42 years. These observations were part of a global effort of the World Meteorological Organization (WMO, 1953) to obtain a global map of the thunderstorm activity. In Brazil they were done in all regions of the country. Figure 1 shows the location of the sites for this period in the southeastern region. The other corresponds to observations made between 1971 and 1984, considering a larger number (500) of observation sites. Again, the period covered by the observations changes considerably in different states, varying from 5 to 14 years. Figure 2 shows the location of the sites for this period in the southeastern region. Most of the observational sites mentioned above are not operational anymore. Only airports still keep recording thunderstorm days at the present time.

The two other datasets used in this study are thunderstormrelated lightning data recorded by two different techniques. One set comes from cloud-to-ground lightning data obtained by the RINDAT network, a LF (low frequency) network that partly covers the Brazilian territory, from 1999 to 2006 (Pinto Jr. et al., 2007). This information is believed to be the most accurate available information to describe the thunderstorm activity in a given region and in this study is considered as a ground truth. Figure 3 shows the location of the lightning sensors in the southeastern region. The sensors are LPATS and IMPACT sensors, and the baseline is typically 


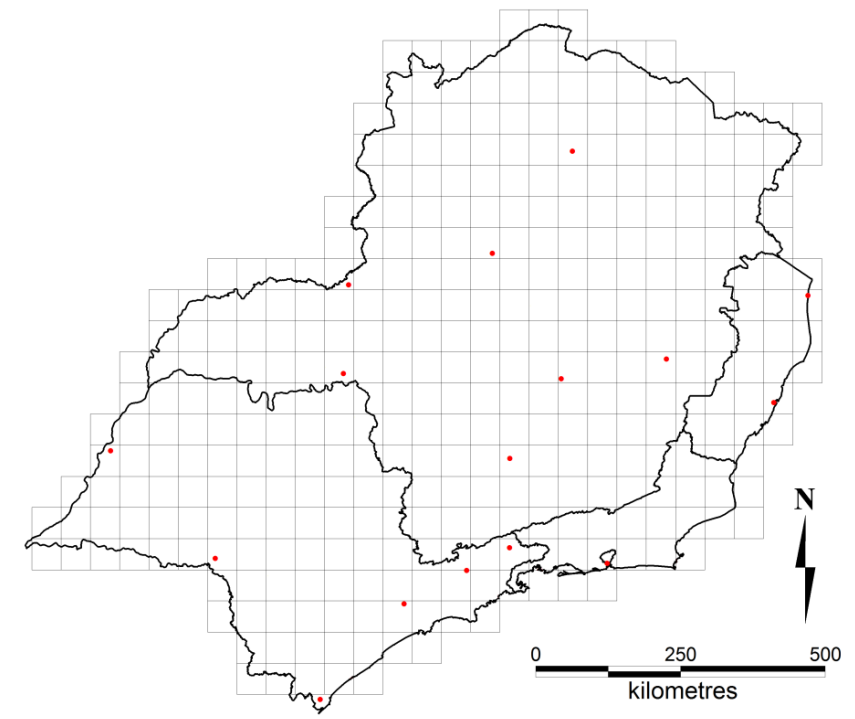

Fig. 3. Location of the lightning sensors of RINDAT for the period of study in southeastern Brazil.

$350 \mathrm{~km}$. The performance of RINDAT network was evaluated extensively in the past (for a review see Pinto Jr., 2009). For southeastern Brazil, the average RINDAT flash detection efficiency is thought to be approximately $85 \%$.

The third dataset is total lightning data observed by the Lightning Imaging Sensor (LIS), an optical sensor on board the Tropical Rainfall Measuring Mission (TRMM) satellite, obtained from 1998 to 2010 (Christian et al., 1999). Due to the orbital characteristics of the TRMM satellite, LIS data need a long period of integration to provide a reliable pattern. In this study, 13 years of data were used, although a definitive pattern was obtained after 10 years of data. LIS data are corrected by local time detection efficiency and view time dependence on latitude (Naccarato et al., 2008) and converted to cloud-to-ground data assuming an intracloud to cloud-toground ratio of 4 , which is obtained by comparing RINDAT and LIS flash data (Pinto Jr. et al., 2003). This value, however, can change at different places due to the predominance of different types of thunderstorms at different locations; consequently, the assumption of a constant ratio should be seen as a first approximation. In particular, in the southern region of Brazil where a larger number of mesoscale convective systems occur compared to the other regions, this ratio is probably higher.

\section{Results and discussion}

Figures 4 and 5 show maps of the average annual number of thunderstorm days for a resolution of approximately $50 \mathrm{~km}$ $\left(0.5^{\circ} \times 0.5^{\circ}\right.$ grid cell $)$. Here, we have used a $0.5^{\circ} \times 0.5^{\circ}$ grid cell for plot thunder records, to avoid a high interpolation error due to the limited number of stations. Figure 4 corre-

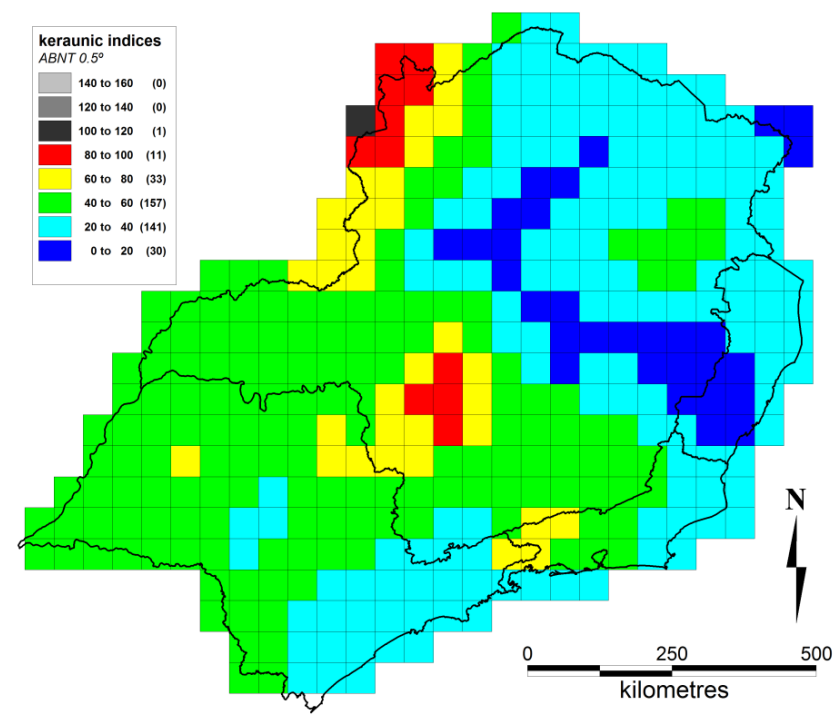

Fig. 4. Map of the average annual number of thunderstorm days in the southeast region of Brazil based on observations between 1910 and 1951 .

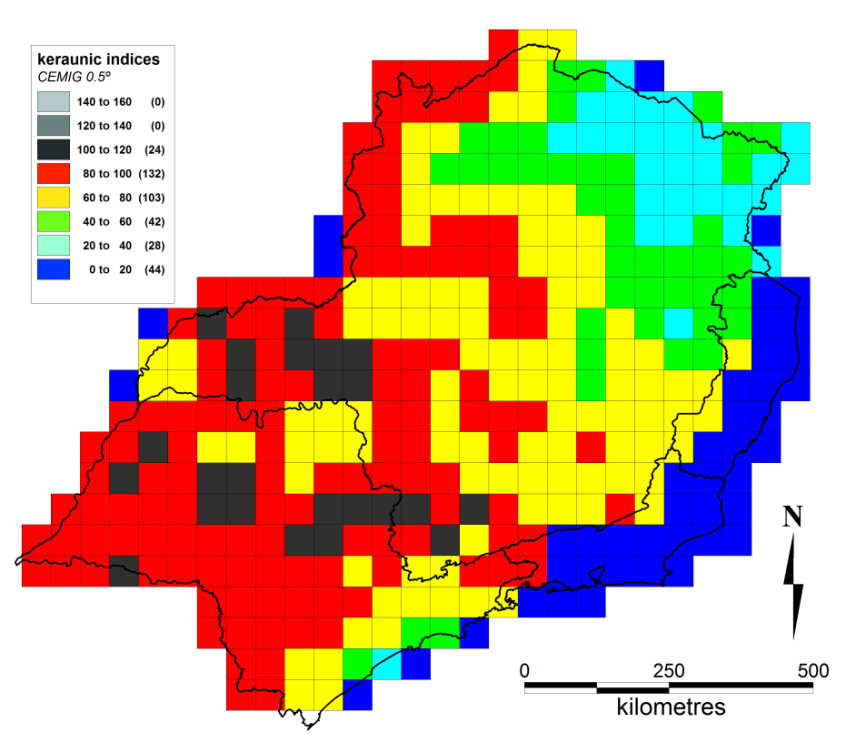

Fig. 5. Map of the average annual number of thunderstorm days in the southeast region of Brazil based on observations between 1971 and 1984.

sponds to the observations made between 1910 and 1951 and Fig. 5 to observations made between 1971 and 1984. We assume here that the interannual variability is negligible, because for some cells the relative differences in Figs. 4 and 5 are higher than $100 \%$. Those differences are too high to be associated only with interannual variations.

Figure 6 shows data obtained from RINDAT from 1999 to 2006 presented in two different ways. Figure 6a shows cloudto-ground lightning flash density in flashes $\mathrm{km}^{-2}$ year $^{-1}$ for a $10 \mathrm{~km}$ resolution, the best resolution that can be obtained 


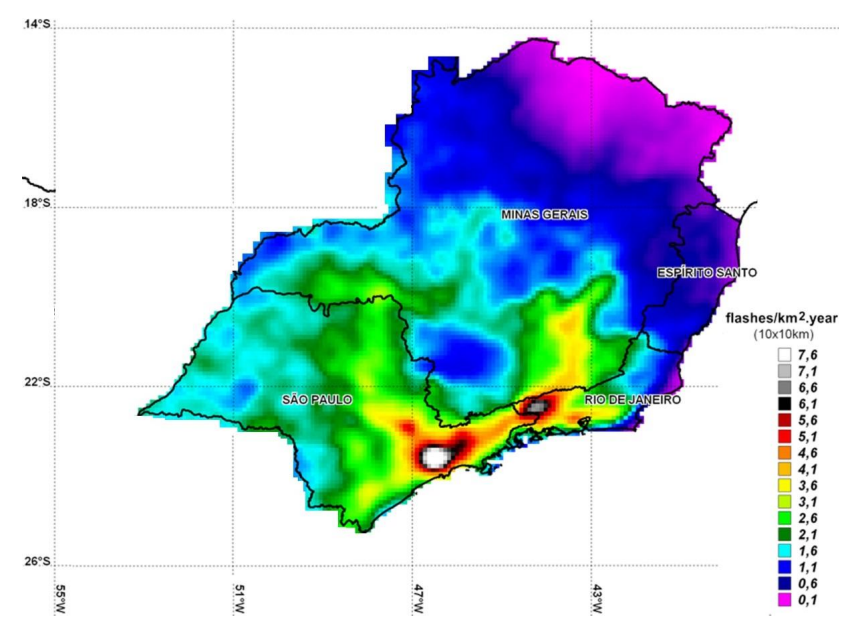

(a)

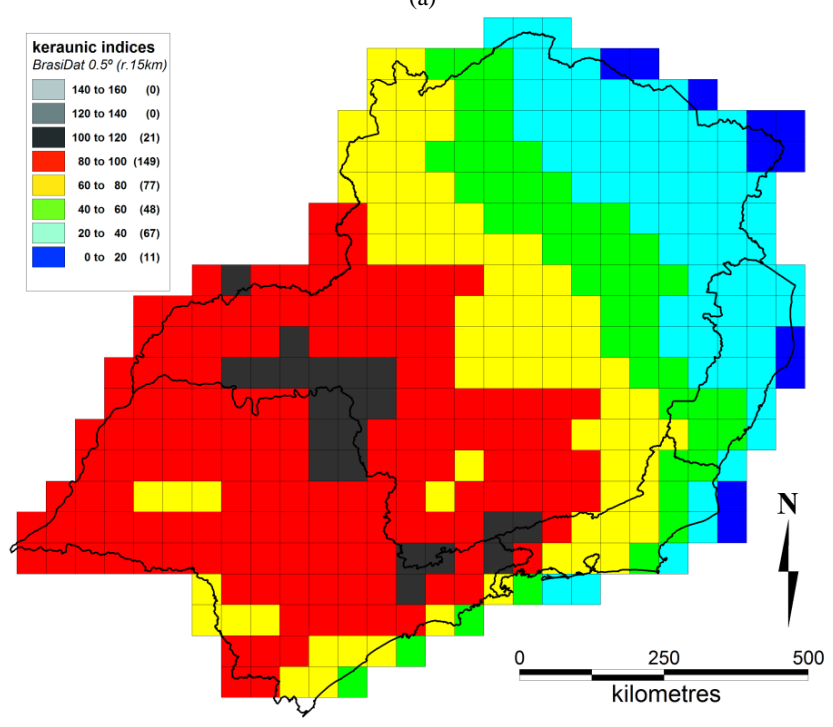

(b)

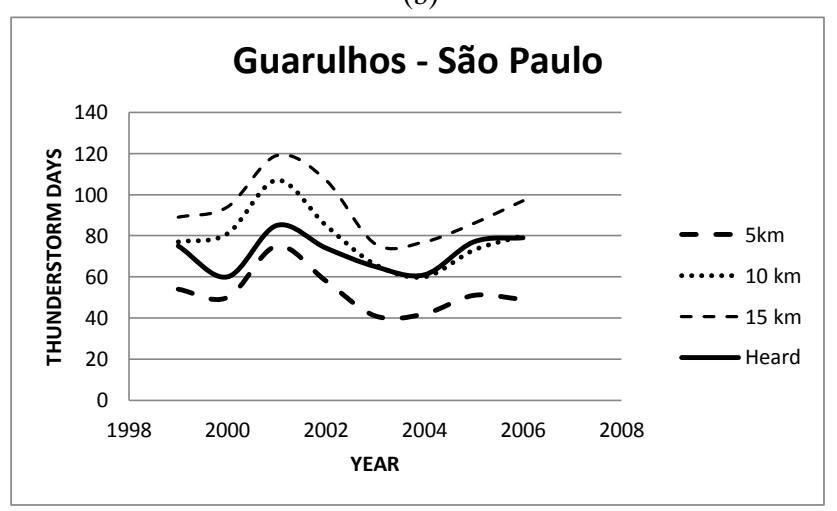

(c)

Fig. 6. Map of the (a) average annual flash density in flashes $\mathrm{km}^{-2}$ year $^{-1}$ and (b) average annual number of thunderstorm days in the southeast region of Brazil based on RINDAT lightning data obtained from 1999 to 2006; (c) thunderstorm days at the Guarulhos International Airport in São Paulo based on man-made observations (heard) and estimated from RINDAT for three different ranges: 5, 10 and $15 \mathrm{~km}$.

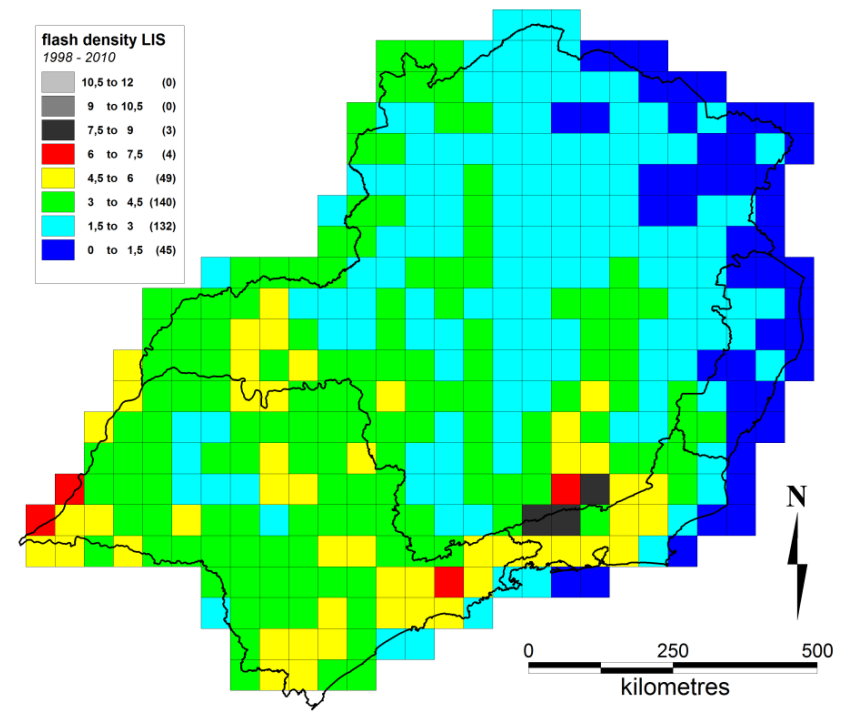

Fig. 7. Map of the cloud-to-ground flash density in the southeast region of Brazil based on lightning LIS data obtained from 1998 to 2010 .

considering the time period. Data are not corrected for the detection efficiency of the system. Figure $6 \mathrm{~b}$ shows RINDAT data converted to thunderstorm days in the same resolution of Figs. 4 and $5(50 \mathrm{~km})$, assuming that if lightning is recorded in a circle of radius of $15 \mathrm{~km}$ (the typical range of thunder audibility - Rakov and Uman, 2003) centered in a given cell in a given day, this day is classified as a thunderstorm day in that cell. Figure $6 \mathrm{c}$ shows a comparison of thunderstorm days computed by thunder observations and estimated from RINDAT data for three different ranges: 5,10 and $15 \mathrm{~km}$ at the Guarulhos International Airport in São Paulo, supporting the $15 \mathrm{~km}$ range of thunder audibility as a reasonable value. The same analysis was done for the other 8 airports in southeast Brazil where thunderstorm observations are still done routinely, obtaining values between 10 and $15 \mathrm{~km}$.

Finally, Fig. 7 shows the cloud-to-ground flash density obtained from LIS data in southeastern Brazil for a resolution of approximately $50 \mathrm{~km}\left(0.5^{\circ} \times 0.5^{\circ}\right.$ grid cell $)$, after correcting the data for detection efficiency and view time and converting total to cloud-to-ground flash as explained previously. The resolution of LIS data is limited by the view time of the satellite and the time period of the data.

From the analysis of Figs. 4 to 7, several aspects related to physical processes responsible for the thunderstorm activity are evident. First, all figures show a systematic decrease from the lower left corner to the upper right corner. This variation is consistent with the location of the SACZ, which develops oriented northwest-southeast along the southeastern region and lasts for several days in the summer causing deep convection. Second, from the high-resolution data in Fig. 6a, it can be seen that the thunderstorm activity is also modulated by the orography, which is shown in Fig. 8. The influence 


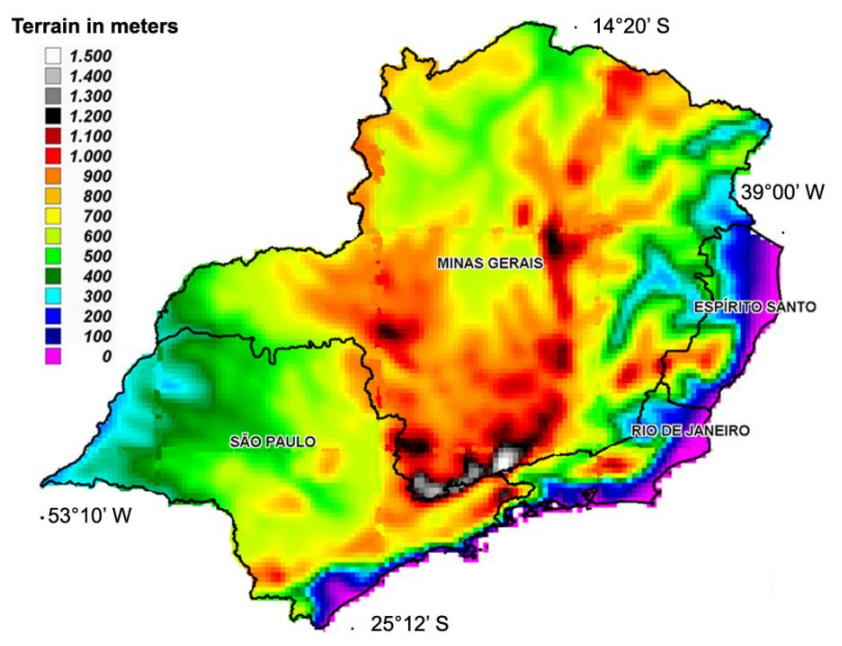

Fig. 8. Map of altitude for southeastern Brazil.

of orography has been discussed also by Bourscheidt et al. (2008). Third, also from Fig. 6a, a large spot (the region in white in the state of São Paulo) of high flash density can be seen, coincident with the location of the city of São Paulo, the largest city of the country with a population larger than 10 million people, suggesting that the urban activity is affecting the thunderstorm activity (Naccarato et al., 2003; Pinto et al., 2004; Farias et al., 2008; Bourscheidt et al., 2012). The effects of orography and urban area are not evident in the low-resolution data in Figs. 4, 5, 6b and 7. In general, these results suggest that the prevailing synoptic pattern associated with thunderstorm activity in southeastern Brazil is the occurrence of frontal systems and their modulation by the SACZ and the orography, and in the particular case of the city of São Paulo by the urban activity.

From the analysis of Figs. 4 to 7, also a practical relevant result is evident. At present time, the observations of thunderstorm days shown in Figs. 4 and 5 are used to produce the isoceraunic maps presented in the Brazilian standard for protection of structures against lightning (ABNT, 2001). The isoceraunic values in the maps are converted to flash density and used in the standards to define the level of protection. In order to test if these maps represent accurately the thunderstorm spatial distribution in this region, a linear correlation analysis between these maps and RINDAT and LIS data was performed. Figure 9 shows the correlation of the RINDAT data converted as described above with the data from Figs. 4, 5 and 7. The highest correlation is found between thunderstorm days computed from RINDAT and LIS flash counts. This result suggests that LIS data can replace thunderstorm days in the Brazilian standards.
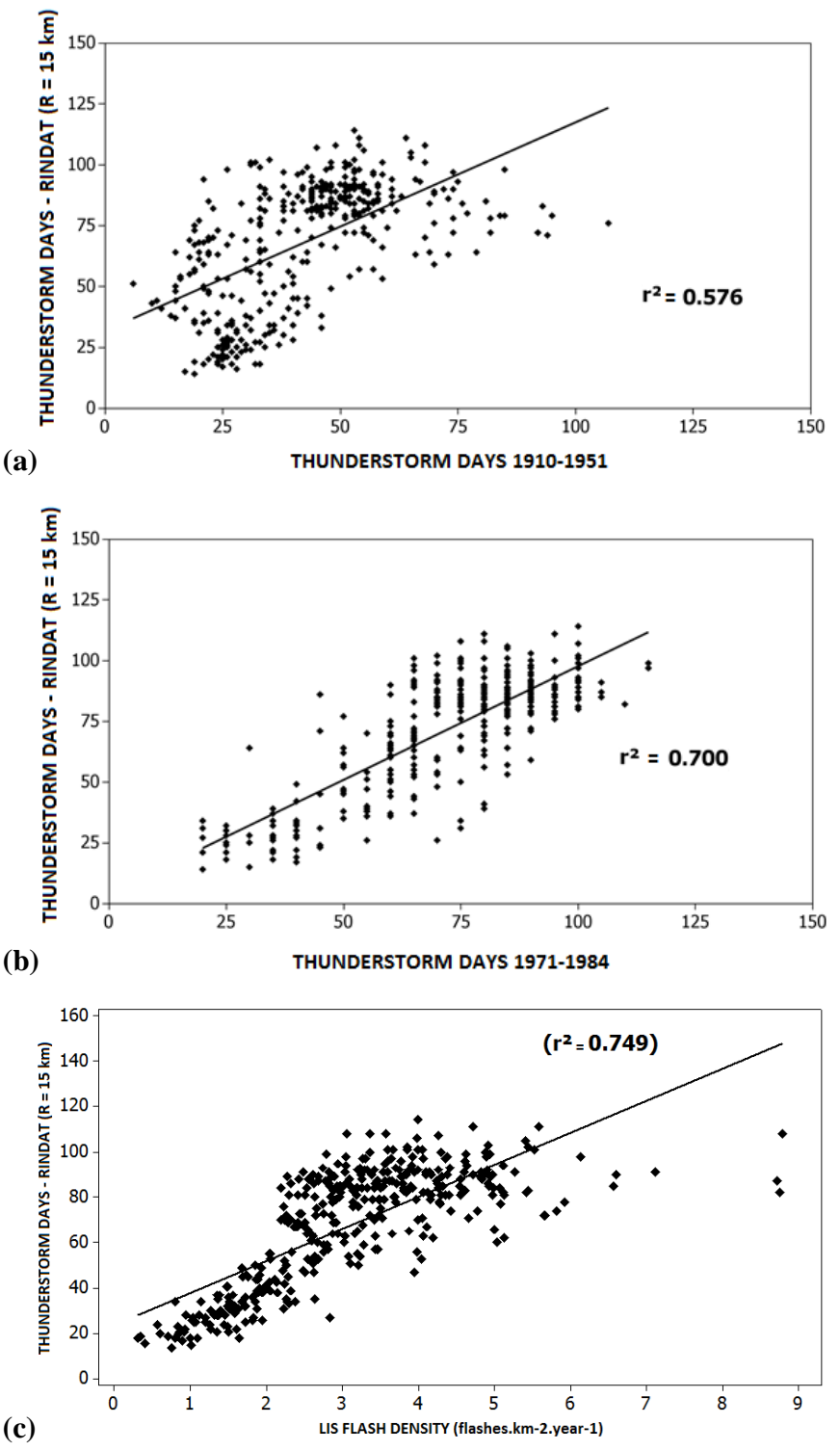

Fig. 9. Scatterplot of the correlation between RINDAT data converted to thunderstorm days with (a) thunderstorm days from 1910 to 1951 (Fig. 4); (b) thunderstorm days from 1971 to 1984 (Fig. 5); and (c) flash density from LIS (Fig. 7). In all plots the value of the correlation coefficient $(r)$ is indicated. All data have a resolution of approximately $50 \mathrm{~km}\left(0.5^{\circ} \times 0.5^{\circ}\right.$ grid cell $)$.

\section{Conclusions}

The results of this study of the thunderstorm activity in southeastern Brazil indicate the following:

- the prevailing synoptic pattern associated with thunderstorm activity in southeastern Brazil is the occurrence of frontal systems and their modulation by the SACZ and the orography, and in the particular case of the city of São Paulo by the urban activity; 
- the thunderstorm day values obtained from 1971 to 1984 with a large number of observational sites represent quite well the thunderstorm spatial distribution in southeastern Brazil as observed by lightning data obtained by the Brazilian lightning location system RINDAT from 1999 to 2006. In contrast, the thunderstorm day values obtained from 1910 to 1951 with a lower number of observational sites fail to represent this spatial distribution. This result suggests that the Brazilian standard for protection of structures against lightning (ABNT, 2001) should be revised;

- the better correlation of RINDAT data with LIS data than with thunderstorm day data suggests that LIS data could be used to replace the past thunderstorm days in the Brazilian standards for lightning protection.

Finally, the results are important to improve our knowledge about the limitations of the different techniques used to record the thunderstorm activity and to support future climatological studies.

Acknowledgements. The author acknowledges the contribution of D. R. Campos and S. Borges for supporting in the data analysis and the Marshall Space Flight Center from NASA for providing LIS data.

Topical Editor P. Drobinski thanks two anonymous referees for their help in evaluating this paper.

\section{References}

ABNT (Brazilian Association of Technical Standards): Protection of structures against lightning, NBR 5419, 2001.

Andrade, K. M.: Climatology and behavior of frontal systems in South America. MsC. Dissertation, São José dos Campos, INPE, 2007 (in Portuguese).

Barros, V., Grimm, A. M., and Doyle, M. E.: Relationship between temperature and circulation in southeastern South America and its influence from El Niño and La Niña events, J. Meteor. Soc. Japan, 80, 21-32, 2002.

Bielec-Bakowska, Z. and Lupikasza, E.: Long-term precipitation variability on thunderstorm days in Poland (1951-2000), Atmos. Res., 93, 506-515, 2009.

Bourscheidt, V., Pinto Jr., O., Naccarato, K. P., and Pinto, I. R. C. A.: The influence of topography on the cloud-to-ground lightning density in South Brazil, Atmos. Res., 91, 508-513, 2008.

Bourscheidt, V., Cummins, K. L., Pinto Jr., O., and Naccarato, K. P.: Methods to Overcome Lightning Location System Performance Limitations on Spatial and Temporal Analysis: Brazilian Case, J. Atmos. Oceanic Technol., 29, 1304-1311, 2012.

Campos, D. R., Pinto Jr., O., Pinto, I. R. C. A., and Farias, W. R. G.: A 11-year study about the spatial and temporal variations of the lightning flash density in the southeastern Brazil, Proceedings of the 11 ICAE Conference, Rio de Janeiro, August, 2011.

Carvalho, L. M. V., Jones, C., and Liebmann, B.: Extreme precipitation events in southeastern South America and large-scale convective patterns in the South Atlantic Convergence Zone, J. Climate, 15, 2377-2394, 2002.
Cavalcanti, I. F. A. and Kousky, V. E.: Climatology of South American cold fronts. Proceedings of the International Conference on Southern Hemisphere Meteorology and Oceanography, Wellington, New Zealand, 2003.

Changnon Jr., S. A. and Hsu, C. F.: Temporal distributions of global thunder days, Final Report NSF ATM-81-14724, Illinois State Water Survey Champaign, Illinois, 1984.

Christian, H. J., Blakeslee, R. J., Goodman, S. J., Mach, D. A., Stewart, M. F., Buechler, D. E., Koshak, W. J., Hall, J. M., Boeck, W. L., Driscoll, K. T., and Boccippio, D. J.: The Lightning Imaging Sensor. Proceedings of the 11st International Conference on Atmospheric Electricity, Guntersville, ICAE, p. 746-749, 1999.

Diendorfer, G., Schulz, W., Cummins, K., Rakov, V., Bernardi, M., De la Rosa, F., Hermos, B., Hussein, A. M., Kawamura, T., Rachidi, F., and Torres, H.: Cloud-to-Ground Lightning Parameters derived from Lightning Location Systems: the effects of system performance, CIGRE Technical Report, Task Force C4.404, 2009.

Farias, W. R. G., Pinto Jr., O., Naccarato, K. P., and Pinto, I. R. C. A.: Anomalous lightning activity over the Metropolitan Region of São Paulo due to urban effects, Atmos. Res., 91, 485-490, 2008.

Naccarato, K. P., Pinto Jr., O., and Pinto, I. R. C. A.: Evidence of thermal and aerosol effects on the cloud-to-ground lightning density and polarity over large urban areas of Southeastern Brazil, Geophys. Res. Lett., 30, 1674-1678, 2003.

Naccarato, K. P., Pinto Jr., O., Holzworth, R. H., and Blakeslee, R.: Cloud-to-ground lightning activity over Brazil using VLF, LF and Lightning Imaging Sensor combined data, Proceedings of 29th International Conference on Lightning Protection (ICLP), Uppsala, 2008.

Pinto, I. R. C. A. and Pinto Jr., O.: Cloud-to-ground lightning distribution in Brazil, J. Atmos. Terr. Phys., 65, 733-737, 2003.

Pinto, I. R. C. A., Pinto Jr., O., Gomes, M. A. S. S., and Ferreira, N. J.: Urban effect on the characteristics of cloud-togroundlightning over Belo Horizonte-Brazil, Ann. Geophys., 22, 697-700, doi:10.5194/angeo-22-697-2004, 2004.

Pinto Jr., O.: Lightning in the tropics: from a source of fire to a monitoring system of climate changes, Nova Science Publishers, 109 p., 2009.

Pinto Jr., O. and Pinto, I. R. C. A.: On the sensitivity of cloud-toground lightning activity to surface air temperature changes at different time scales in São Paulo, Brazil, J. Geophys. Res., 113, D20123, doi:10.1029/2008JD009841, 2008.

Pinto Jr., O., Pinto, I. R. C. A., and Faria, H. H.: A comparative analysis of lightning data from lightning networks and LIS sensor in the North and Southeast of Brazil, Geophys. Res. Lett., 30, 1073, doi:10.1029/2002GL016009, 2003.

Pinto Jr., O., Pinto, I. R. C. A., and Naccarato, K. P.: Maximum cloud-to-ground lightning flash densities observed by lightning location systems in the tropical region: A review, Atmos. Res., 84, 189-200, 2007.

Rakov, V. A. and Uman, M. A.: Lightning: Physics and Effects, Cambridge University Press, Cambridge, 687 p., 2003.

Wei, J., Liu, M., Zhang, B., and Yu, J.: Analysis of trends of thunderstorms in 1951-2007 in Jiangsu province, J. Trop. Meteor., 17, 58-63, 2011.

Wiedenmann, J. M., Lupo, A. R., Mokhov, I. I., and Tikhonova, E. A.: The Climatology of Blocking Anticyclones for the Northern 
and Southern Hemispheres: Block Intensity as a Diagnostic, J. Climate, 15, 3459-3473, 2002.
WMO (World Meteorological Organization): World distribution of thunderstorm days, Repartition mondiale des jours d'orage, 1953. 